\title{
Airborne Aerosols and Human Health: Leapfrogging from Mass Concentration to Oxidative Potential
}

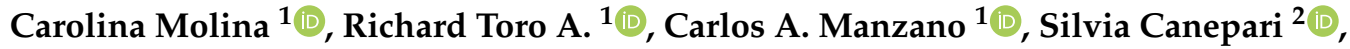 \\ Lorenzo Massimi $^{2}$ (D) and Manuel. A. Leiva-Guzmán $1, * \mathbb{D}$ \\ 1 Department of Chemistry, Faculty of Science, University of Chile, Las Palmeras 3425, Nuñoa, \\ Santiago 7800003, Chile; carolina.molina@um.uchile.cl (C.M.); rtoro81@uchile.cl (R.T.A.); \\ carlos.manzano@uchile.cl (C.A.M.) \\ 2 Department of Chemistry, Sapienza University of Rome, P. le Aldo Moro, 5, Rome 00185, Italy; \\ silvia.canepari@uniroma1.it (S.C.); 1.massimi@uniroma1.it (L.M.) \\ * Correspondence: manleiva@uchile.cl; Tel.: +56-2-297-87370
}

Received: 6 July 2020; Accepted: 26 August 2020; Published: 28 August 2020

\begin{abstract}
The mass concentration of atmospheric particulate matter (PM) has been systematically used in epidemiological studies as an indicator of exposure to air pollutants, connecting PM concentrations with a wide variety of human health effects. However, these effects can be hardly explained by using one single parameter, especially because PM is formed by a complex mixture of chemicals. Current research has shown that many of these adverse health effects can be derived from the oxidative stress caused by the deposition of PM in the lungs. The oxidative potential (OP) of the PM, related to the presence of transition metals and organic compounds that can induce the production of reactive oxygen and nitrogen species (ROS/RNS), could be a parameter to evaluate these effects. Therefore, estimating the OP of atmospheric PM would allow us to evaluate and integrate the toxic potential of PM into a unique parameter, which is related to emission sources, size distribution and/or chemical composition. However, the association between PM and particle-induced toxicity is still largely unknown. In this commentary article, we analyze how this new paradigm could help to deal with some unanswered questions related to the impact of atmospheric PM over human health.
\end{abstract}

Keywords: airborne aerosols; reactive oxygen species (ROS); health effects; oxidative potential

\section{Introduction}

In the last 50 years, the share of the population living in urban areas has increased from $36.5 \%$ to $55.3 \%$, and it is expected to reach $68.4 \%$ by 2050 [1]. This amount of people and activity in urban areas exerts increasing amounts of stress on the natural environment, and one of the major problems associated with an urbanized world is the air pollution and its impact on human health. This is specifically associated with airborne particulate matter (PM) [2-5]. Health effects and diseases related to high PM concentrations are diverse. PM has been associated with cancer, diabetes, cardiovascular diseases, hypertension, respiratory, and neurological diseases [6-11].

Mass concentration has been a common approach used to correlate the atmospheric PM and its effects on human health. At first, total suspended particles and $\mathrm{PM}_{10}(10 \mu \mathrm{m}$ in diameter, "coarse" if $>2.5 \mu \mathrm{m}$ ) were associated with higher mortality rates [12]. Later, fine PM (with diameter less than $2.5 \mu \mathrm{m})$ and ultrafine $(0.1 \mu \mathrm{m}$ or less) particles started to gain attention for its ability to penetrate deeper in the respiratory system, traveling to other organs through the bloodstream [13-18]. $\mathrm{PM}_{2.5}$ has been associated with preterm births, accounting for $18 \%$ of the total preterm births globally [19] and with a decrease of the corpus callosum volume during gestation [20]. However, it has been proven that some $\mathrm{PM}_{10}$ with low density can also deposit in the lungs, thus having a higher health risk than 
expected [21]. The relative estimated risk, according to the U.S. Environmental Protection Agency (EPA), accounts for an extra 2.5-5\% on all-age mortality rates for each $10 \mu \mathrm{g} \mathrm{m}^{-3}$ or $25 \mu \mathrm{g} \mathrm{m}^{-3}$ increase in the concentration of $\mathrm{PM}_{10}$ or $\mathrm{PM}_{2.5}$, respectively [22]. Another study in New England established that for each $10 \mu \mathrm{g} \mathrm{m}^{-3}$ increase on $\mathrm{PM}_{2.5}$ concentration, the mortality risk associated with short (2-day) and long-term (1-year) exposures increased by $2.14 \%$ and $7.52 \%$, respectively, for population over 65 years old [23]. This study suggested that some PM concentrations, even below the EPA standards, were positively associated with higher mortality rates after chronic exposures.

However, the concentration of atmospheric PM should not be the only relevant factor to be considered. Its chemical composition and size vary greatly depending on meteorological factors, emission sources, transformation reactions and aging in the atmosphere [24-29]. PM contains organic compounds, including biological materials, such as pollen, spores, plants or animal waste, and inorganic ions, crustal materials, elemental carbon, and metals. These components, either alone or as part of a mixture, can induce negative effects on human health. For instance, sulphate ions have been associated with an increase in morbidity and mortality rates, due to their acidic properties or their interaction with other components-sometimes increasing the bioavailability of other metals or catalyzing organic reactions [30]. Regarding organic components, the exposure to PAHs has been associated with lung, skin and bladder cancer, in addition to endocrinal and immune diseases [31]. Elemental carbon has been associated with hospital admissions for cardiovascular diseases, while organic carbon was associated with respiratory diseases [32-34]. Occupational exposure and cigarette smoke with high concentrations of $\mathrm{Cd}$ are positively correlated with lung and kidney cancer [35]. Risk of breast cancer, due to the exposure to transition metals was evaluated through a follow-up study of 50,884 participants, finding that higher concentrations of $\mathrm{Cd}$, $\mathrm{Hg}$, and $\mathrm{Pb}$ were associated with a high risk of breast cancer [36]. Additionally, chemical components and physical properties may have antagonistic or synergistic effects that must be evaluated. Therefore, the evaluation of the effects of atmospheric PM on human health needs to be addressed carefully.

Epidemiological studies are generally used to evaluate the human health effects of atmospheric PM. New approaches are emerging to reduce the uncertainty associated with these results and to answer the following questions: (i) What concentration of PM is "risk-free" for human health? (ii) How does PM damage human health? (iii) Is this damage caused by the physical properties of the PM (size and its penetration ability) or by its chemical composition? (iv) Is the damage caused by the interactions between the PM chemical constituents? (v) Which chemical constituents are responsible for these effects? (vi) Is there a method to measure the oxidative properties of PM and represent its physical and chemical characteristics? Finally, (vii) what would be the best metric, other than PM mass concentration, for determining the association between the exposure to PM and the adverse effects on human health? Answering these questions will help us understand the mechanisms of action of PM pollution on human health.

\section{Leapfrogging to Oxidative Potential}

Although PM mass concentration has been used as an exposure indicator, it may underestimate the overall impact of PM, since it does not consider the different sizes, compositions and toxicological effects of its components and their interactions with other pollutants. The negative health effects posed by the particles cannot be explained by a single parameter, such as mass concentration [37], and thus, significant empirical uncertainty in the results obtained from epidemiological studies is observed. It is possible that a specific major chemical component (i.e., a large contributor in terms of mass) has a low or very low toxicological activity, consequently inducing moderate or no negative effects on human health, while minority or trace chemical components may have high toxicological activity. In this sense, the PM mass concentration is a poor metric for explaining the mechanisms by which PM exposure can induce deterioration in human health [38]. This limitation can be overcome by identifying the possible relationship between PM toxicity and its specific physical and chemical properties. During the last few years, the complex and variable composition of PM has been widely studied, and several PM properties have been identified as important in the determination of its potential health and environmental effects, but they are not entirely conclusive [39-42]. 
The specific mechanisms of action by which exposure to PM may lead to adverse health effects are still largely unknown [43-45]. Non-oxidant and oxidant mechanisms have been reviewed. Studies for non-oxidant mechanism have shown that particles may activate the aryl-hydrocarbon receptor (AhR), activating cytokines, proinflammatory genes, suppressing the cholesterol synthesis and affecting membrane functions [46]. Other routes linked extracellular signaling (or particle bounding to scavenger receptors) to induce inflammatory responses. Lastly, some components of particles may act as endocrine disruptors, altering the hormone synthesis process, excretion, transport, and competing during binding to carrier proteins or receptor in target cells [47].

Substantial research has been dedicated to understanding the oxidation mechanisms. In many of these studies, PM health effects have been attributed to its oxidative or oxidant-generating properties [48-51]. Current research hypothesizes that many of the adverse health effects are derived from oxidative stress in biological systems caused by the deposition of PM into the lungs [45,52]. This emerging hypothesis is called the oxidative stress paradigm [53]. It proposes that oxidative stress proceeds through two mechanisms. The first mechanism is related to intrinsic oxidation-reduction reactions resulting from redox-active substances in the PM [54,55]. This mechanism may be influenced by specific chemical compounds, such as soluble transition metals, which can reduce the dissolved oxygen into reactive oxygen species (ROS) and nitrogen-containing oxidants (such as nitric oxide, NO.), into reactive nitrogen species (RNS) $[56,57]$. ROS is a collective term comprising chemically reactive oxygen radicals, e.g., superoxide $\left(\mathrm{O}_{2} \cdot{ }^{-}\right)$, hydroxyl $(\cdot \mathrm{OH})$, peroxyl $\left(\mathrm{RO}_{2} \cdot\right)$, and alkoxyl $(\mathrm{RO} \cdot)$, and/or oxygen-derived species, such as hypochlorous acid $(\mathrm{HOCl})$, ozone $\left(\mathrm{O}_{3}\right)$, singlet oxygen $\left({ }^{1} \mathrm{O}_{2}\right)$, and hydrogen peroxide $\left(\mathrm{H}_{2} \mathrm{O}_{2}\right)$-which are oxidizing agents and can be converted into radicals [58,59]. In living organisms, ROS represent the most important class of radical species from a biochemical point-of-view [58,59]. Although ROS and other radicals are continually formed in the human body as a natural by-product of aerobic metabolism, the enhanced generation of radicals induced by PM can overwhelm the antioxidant defenses [53].

The second mechanism is the biological response to inhaled PM or cell-mediated oxidant generating capacity. This mechanism is believed to be associated with oxidative phosphorylation in cells, which occurs through the sequential addition of electrons to dissolved oxygen [52,60-62]. The amount of ROS formed by PM is several orders of magnitude higher than the concentrations that cause oxidative stress, which is the main cause of the inflammatory response. Figure 1 summarizes these mechanistic pathways of PM producing oxidative stress and inflammatory responses. Thus, oxidative stress represents a relevant mechanism of toxicity derived from PM, and the oxidative potential (OP) measurement in PM can be a first step in the elucidation of the subsequent downstream processes. However, the relatively complex measurement processes in biological systems make it difficult to monitor the ROS parameter in the environment.

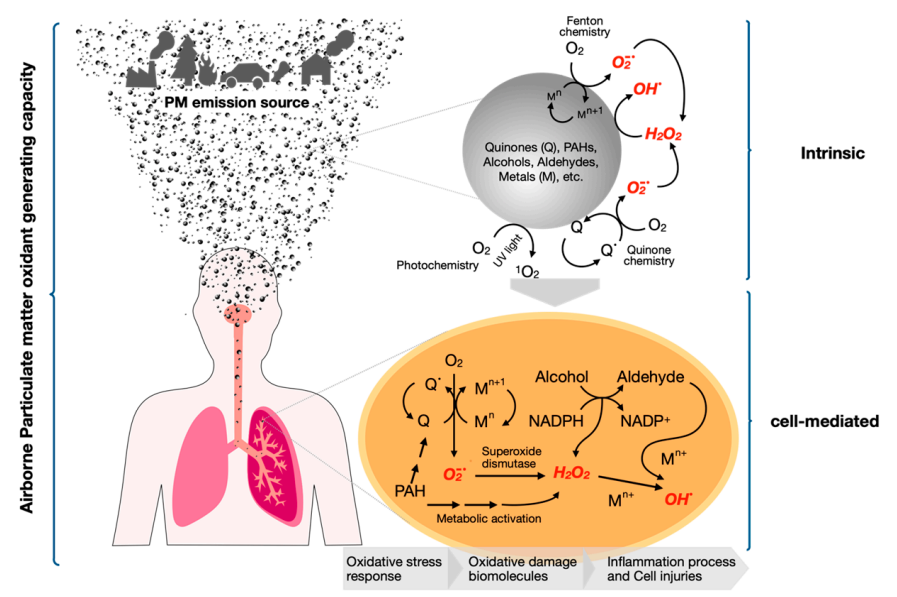

Figure 1. Schematic mechanistic pathways of particulate matter (PM) producing oxidative stress and inflammatory response. 


\section{Oxidative Potential Measurement Assays}

Based on this possible route linking aerosol chemistry to human health, numerous studies have focused on measuring the oxidative properties of ambient particles. These measurements have been done using cell-free, in-vitro or ex-vivo methods (cell cultures), in-vivo assays or epidemiological studies.

Cell-free tests are based on the consumption of a molecule (i.e., usually antioxidants) or by direct measurement of the formation of ROS from PM extracts. They are helpful for a rapid initial hazard screening, require less controlled environments, are simpler and cheaper than those using biological systems, and allow OP environmental monitoring. However, cell-free assays fail to explain and predict physiological responses. OP cell-free assays are diverse [63] and include dithiothreitol (DTT) assay [64-66], ascorbic acid (AA) assay [67,68], glutathione (GSH) [69] and dichlorofluorescin (DCFH) assays [70,71] and electron spin (or paramagnetic) resonance (ESR) [72,73]. ESR measures the generation of ROS via electron spin resonance, while the DTT, GSH and AA assays measure the depletion rate of chemical proxies for cellular reductants (DTT) or antioxidants (AA), which is proportional to the generation rate of ROS. On the contrary, particle-bound ROS measurements, such as the DCFH assay, use fluorescent-based techniques to measure concentrations of specific ROS, usually the hydroxyl radical or hydrogen peroxide, in PM samples $[74,75]$. These methods usually reveal a different response to the chemical constituents of PM. In recent studies [76-79], cell-free assays have been used simultaneously. Piacentini et al., 2019 [76], compared the DTT, AA and DCFH assays applied to seven types of widespread atmospheric dust samples (e.g., brake dust, pellet ash, road dust, soil dust, coke dust and Saharan dust, homogenized and sieved at $50 \mu \mathrm{m}$ ) characterized by different chemical compositions. The assays provided different results for each dust sample, in which AA showed a higher response to elemental components related to brake dust, while DTT and DCFH showed higher responses to combustion sources. This confirms the idea that none of these assays should be a "one-size-fits-all" approach to measure ROS/RNS in PM. A recent review [74] compiled epidemiological studies in which associations were stronger when using the OP of PM, instead of its concentration. The DTT assay has been the most studied, and showed positive associations with fractional exhaled nitric oxide (FeNO), asthma, congestive heart failure and ischemic heart disease. Other assays that showed positive associations were ESR and AA (with FeNO) and GSH (using a surrogate lung fluid) with lung cancer mortality [48,72,73,80-83].

In-vitro and ex-vivo assays use cell cultures to evaluate the effects of PM. Common cell cultures used are macrophages (RAW 254.7), human lung alveolar (A549), bronchiolar (BEAS-2B) and bronchial epithelial cells (16HBE, NHBE) [84-87]. The evaluation of OP or oxidative stress in cells after exposure to PM has been performed using different biological parameters like cell viability, inflammatory cytokines (e.g., IL-6, IL-8, IL-10 and TNF-alpha), DNA and lipid damage, gene and protein expressions, antioxidant enzymes activities, ROS generation, oxidative stress biomarkers (Heme oxygenase-1) and AhR signaling [84-93]. A recent approach is called "organ-on-a-chip" [94-97]. This multi-cellular culture simulates functions and microenvironments of organs (e.g., lungs, kidney, skin, heart, brain and bone marrow), they are more representative of human physiological functions, reduce costs and do not have ethical concerns as in-vivo models. Lung-on-a-chip models have found an increasing generation of ROS, apoptosis, and inflammatory responses after acute $\mathrm{PM}_{2.5}$ exposures [94]. On a human microvascular model, exposure to indoor airborne nanoscale particles showed inflammation induced by ROS and disruption on coagulation functions [97].

In-vivo assays are based on exposing animals or humans to PM and evaluating biomarkers for oxidative stress in blood, urine, or exhaled breath condensate [98-101]. Delfino et al., 2013 found a strong association between the potential intrinsic particle-induced ROS generation and the fractional exhaled nitric oxide, a biomarker of airway inflammation, in schoolchildren with persistent asthma in southern California [48]. However, they found that the ambient $\mathrm{PM}_{2.5}$ mass concentration was not associated with biomarkers of airway inflammation. Cell-free OP measurements and cellular oxidative stress have shown to be associated with ROS/RNS generation, antioxidants degradation and oxidative damage to biomolecules. DTT is the only assay associate to cytotoxicity [63]. 


\section{OP Environmental Monitoring}

Environmental OP values have been estimated using the methods described above, which can be expressed as the OP normalized to the volume of air containing a certain concentration of PM, or as the OP normalized to the mass of particles, representing the intrinsic OP of the PM analyzed.

Sample collection of ambient PM for OP evaluation has been done by different methods: High and low volume samplers impacting particles in different types of filters, Versatile Aerosol Concentration Enrichment System (VACES), Particle Into Liquid Sampler (PILS), BioSampler based on the condensation of particles, and Micro-Orifice Uniform Deposition Impactor (MOUDI) for size-segregated samples [93,102-105].

Seasonal variability has been observed for the estimated OPs of PM samples at different locations worldwide. OP measured by the AA, GSH and DTT assays in Chamonix, France was found to be between 3 to 6-fold higher in winter compared to summer [106]. This was mainly due to the major strength of typical winter sources, such as domestic biomass burning for heating. In fact, DTT assay is deemed to be specifically sensitive toward particles released by biomass burning during the colder season [106-108]. However, other studies have found higher OP for PM samples collected during summer compared to winter (1.5 to 2 times higher), and this was related to the concentration of water-soluble organic components associated with the photochemical formation of secondary organic aerosols [71,109]. In contrast, significant DNA damage was attributed to the water-soluble trace elements [110]. Some studies provide a systematic long-term (year-round) OP estimation for atmospheric PM samples collected at urban and sub-urban areas. Average results for the OP of PM estimated by the DTT assay are: Atlanta $0.22 \pm 0.07 \mathrm{nmol} \mathrm{min}^{-1} \mathrm{~m}^{-3}$ [79], Salento $0.24 \pm 0.07 \mathrm{nmol} \mathrm{min}^{-1} \mathrm{~m}^{-3}$ [111], Athens $\quad 0.33 \pm 0.20 \mathrm{nmol} \mathrm{min}{ }^{-1} \mathrm{~m}^{-3}$ [112], Xi'an $0.51 \pm 0.1 \mathrm{nmol} \mathrm{min}^{-1} \mathrm{~m}^{-3}$ [113], Hangzhou $0.62 \mathrm{nmol} \mathrm{min}^{-1} \mathrm{~m}^{-3}$ [114], and Beijing $12.26 \pm 6.82 \mathrm{nmol} \mathrm{min}^{-1} \mathrm{~m}^{-3}$ [109].

Other studies, focused on determining spatial variability, show that the OP of $\mathrm{PM}_{10}$ samples measured by ESR spectroscopy was 4.5 times higher in an industrial city compared to a neighboring rural town, despite having similar atmospheric $\mathrm{PM}_{10}$ concentrations [115]. Similarly, higher OP values for $\mathrm{PM}_{10}$ and $\mathrm{PM}_{2.5}$ samples measured by EPR were found at locations close to highways and roads, compared to urban background locations and suburban background locations in the Netherlands. Furthermore, the values observed were 3.6 to 6.5 times higher at the urban locations compared to the suburban locations [116]. In Los Angeles, the USA, the redox activity (measured by the DTT assay) of the PM size-segregated samples collected in various sites (e.g., road tunnel, freeway, background sites) revealed the highest $\mathrm{OP}$ for $\mathrm{PM}_{0.15}$ samples collected in a road tunnel, which were directly influenced by emission sources [117].

Automatization and online measurements have been a growing area of study, as they have the potential to significantly reduce analysis time, materials and would also help to obtain data with better time resolution. Some automated systems developed are based on the DCFH [118,119], DTT [120-123], .OH-TPT assays [124], and a multi endpoint ROS activity analyzer for DTT, -OH in DTT and AA, GSH, .OH in SFL [125]. Those advances contribute to scaling-up the research efforts and to design future monitoring applications.

Personal monitoring has gained relevance in recent years. These studies combine spatiotemporal resolution and a more representative exposure of the organism. Quinn et al., 2018 [126] used a microenvironmental aerosol sampler (AMAS) that uses a filter for different microenvironments (e.g., home, school and transport). The estimated OP was then normalized to the time spent in each place, and samples collected at homes showed the highest OP, possibly related to higher black carbon concentrations indoor. Other studies evaluating total personal and indoor/outdoor exposure show that OP (mass normalized) was higher on personal monitoring $[127,128]$. These studies also show that the use of air cleaners can reduce the measured OP and ROS exposure in indoor environments (related to roadway emissions), but they do not significantly reduce overall personal exposure, that could be related to other daily activities $[129,130]$. 


\section{OP and Chemical Composition of PM}

PM components involved in the formation of ROS include heavy metals, organic carbon (OC), polycyclic aromatic hydrocarbons (PAHs), quinones and others [55,131-133]. The OP of the PM is attributed, in part, to the content of transition metals, such as $\mathrm{Fe}, \mathrm{V}, \mathrm{Cr}, \mathrm{Mn}, \mathrm{Co}, \mathrm{Ni}, \mathrm{Cu}, \mathrm{Zn}$, and Ti [134] and soluble transition metal species [131,135-137]. Metals, such as $\mathrm{Fe}, \mathrm{Cu}, \mathrm{Co}$, and $\mathrm{V}$, can initiate ROS formation both directly and indirectly through redox-mediated mechanisms [71,136,138-140]. Additionally, transition metals may act as catalysts through Fenton-type reactions $[54,65,138]$ and promote the formation of ROS. The importance of the role of metals in ROS activity is supported by a study by the California Air Resources Board and the California Environmental Protection Agency [134], which found that the removal of metals from diesel PM via metal chelation treatment reduced the ROS activity by an average of $77 \%$. Similarly, ultrafine particles with metallic components were found to produce increasing ROS activity, and different metal compositions were linked to the different levels of ROS and inflammation observed [134]. For example, based on a correlation analysis of the PM concentrations of soluble metals and the redox activity of the samples evaluated by the DTT assay, Charrier et al., 2015 [131] found that approximately 80\% of DTT consumption can be attributed to metals in $\mathrm{PM}_{2.5}$ samples. The potential sources of transition metals $(\mathrm{Fe}, \mathrm{Cr}$, and $\mathrm{Mn}$ ) in PM include a variety of high energy/combustion sources, such as vehicle exhaust, coal and fuel oil burning, welding fumes, steel processing, and waste incineration [141]. An example of the impact of emission sources can be found in a study of PM emitted from oil combustion, in which the PM-induced redox activity was associated with residual oil combustion tracers (e.g., V and Ni) [136] at multiple locations and size ranges. It is important to mention that $\mathrm{OP}$ assays have different responses to metals [74]. Generally, AA is deemed to be particularly sensitive to transition metals and has been strongly positively correlated with the main elements tracing non-exhaust traffic emissions, such as $\mathrm{Cu}, \mathrm{Fe}$ and $\mathrm{Mn}$. On the other hand, various chemical components in atmospheric aerosols have been demonstrated to be well-correlated with DTT, including water-soluble transition metal ions ( $\mathrm{Cu}$ and $\mathrm{Mn}$ mostly), water-soluble organic compounds and quinones. Numerous studies have shown strong correlations of DTT with biomass burning tracers, such as $\mathrm{K}$ and organic compounds like levoglucosan.

The oxidative potential of particulate matter has also been attributed to certain organic compounds. A wide variety of organic compounds in PM (such as quinones and PAHs) induce oxidative stress [142,143]. Particles generated by combustion processes, from wood smoke and diesel exhaust, contain quinones and nitro-derivatives of PAHs, oxygenated PAH, and halogenated aromatic hydrocarbons that are related to the redox activity of PM [142,143] and can be involved in the redox cycle, resulting in the formation of ROS [144,145]. The redox activity may be more strongly correlated with high molecular weight PAHs [146]. Semiquinone-like compounds in the PM samples may be responsible for radical production, which is similar to the reduction of dioxygen by hydroquinone and semi-quinone radicals [147,148]. Charrier et al., 2015 [131] measured species in particles collected from the San Joaquin Valley of California and found that approximately $20 \%$ of the redox activity could be attributed to quinone species when budgeting the redox activity observed. Further research will be needed to identify the quinone species and the relationship between these compounds and the redox potential that leads to the generation of ROS.

The organic carbon (OC) and water-soluble organic carbon (WSOC) content in PM has also been correlated with redox activity $[133,149]$. Samples collected in six European cities induced greater inflammatory and cytotoxic response on mice for $\mathrm{PM}_{0.2-2.5}$ compared to $\mathrm{PM}_{2.5-10}$. Dicarboxylic acids, oxidized PAHs and monosaccharide anhydrides from incomplete local combustion and photochemical reactions may have generated an immunosuppressive effect on mice [150].

Secondary organic aerosols (SOA) formed under oxidant conditions have shown to be highly reactive towards OP assays. High concentrations of $\mathrm{NOx}$ and $\mathrm{O}_{3}$ generate more oxidizing SOAs than when their concentrations are low [151]. Naphthalene, toluene, isoprene (epoxides and hydroxy hydroperoxides) and methacrolein derived SOA showed similar OP or ROS generation compared to biomass burning and $\mathrm{PM}$ from diesel exhaust [93,151-155]. Inorganic ions $\mathrm{SO}_{4}{ }^{2-}$ and $\mathrm{NO}_{3}{ }^{-}$may 
produce an acidic environment, which would affect other components, like transition metals, increasing their solubility and having synergistic contributions on oxidative stress [114,156,157].

Lastly, bioaerosols or the biological fraction of PM have an important role in ROS production, and fungal spores showed 10 times more oxidative reactivity than bacterial cells [158]. Synergistic and antagonistic effects between chemical components of PM has been found to affect the OP measured by DTT assay. Mixtures of $\mathrm{Fe}, \mathrm{Cu}$ and $\mathrm{Mn}$ were evaluated with quinones and humic-like substances (HULIS) finding that its interaction varies with the concentration of components. Quinones are synergic or additive with $\mathrm{Fe} ; \mathrm{Cu}$ have antagonistic interactions with phenanthrenequinone (PQ), but additive with 1,2-naphthoquinone (1,2-NQ) and 1,4-naphthoquinone (1,4-NQ); Mn interacted synergistically with 1,4-NQ in DTT, but antagonistically with PQ [159-161]. HULIS and Cu mixtures suppress OP at low $\mathrm{Cu}$ concentration, while an enhancement of OP was found in mixtures of HULIS and Mn [160]. Guo et al., 2020 [161] established a new approach to quantify the interactions of PM components that will be useful to characterize interactions among components helping to describe and understand OP measurements.

\section{Oxidative Potential and Size Segregated PM}

Particle size can also be critical in mediating PM oxidative stress [162]. Because of their variable concentration, number, surface area and high pulmonary deposition efficiency [136,137], ultrafine particles may be more biologically active than coarse or fine particles [163]. The AA assay has been found to be particularly sensitive to coarse particles (mainly released by mechanical and abrasive processes). In contrast, the DTT and DCFH assays resulted in being more sensitive toward fine particles, mainly originated by condensation and accumulation of ultrafine particles released by combustion processes [134]. In fact, transition metals, to which AA is deemed to be more sensitive, are especially present in the coarse fraction, since they are mostly released by mechanical and abrasive processes, such as brake abrasion. On the contrary, water-soluble metals and organics, which are generally associated with higher intrinsic ROS activity, and to which DTT and DCFH seem to be more sensitive, are mainly released by combustion processes in ultrafine particles that generate the fine fraction of PM by condensation/coagulation processes. We can thus assume that the relationship between PM size and its OP mainly depends on the different chemical composition of the PM in different size fractions. However, a higher activity has been found for smaller particles overall. Evaluating particles collected in Los Angeles from November 2001 to March 2002, Li et al., 2003 found that the DTT decay rate per $\mu \mathrm{g}$ of PM was 8.7 times greater for $\mathrm{PM}_{0.15}$ compared to fine particles, and 21.7 times greater compared to coarse particles [162]. Likewise, Cho et al., 2005 reported a similar trend examining particles collected in Los Angeles; the redox activity, when normalized to the particle mass, decreased moving from ultrafine to fine and from fine to coarse particles [64].

The effect of PM size on the OP of samples collected in an urban setting using a MOUDI sampler [61] was determined by the DCFH assay. The results show that the OP was higher for particles in the ultra-fine size range. This finding may be explained by the fact that ROS can be produced by photochemical reactions or vapor phase condensation on the particles. Similarly, other studies using DTT assays also showed a higher redox activity for PM samples in the ultrafine mode, while the activity decreased for PM samples in the fine and coarse modes [61]. A significant correlation was shown between particle numbers (but not particle mass) and the oxidative potential of diesel exhaust, again indicating that the particle size and composition strongly influence the particle OP $[105,164-166]$.

The OP of nanoparticles (NP) has been explored and discussed, due to their diversity in size, morphology, composition and synthesis process [39]. The OP for NP is proposed to be expressed in terms of mass and surface. Different NP (black carbon-based) were compared to diesel particles, and smaller NP $(12 \mathrm{~nm})$ with larger surface area and post-treated by the manufacturer with oxidants, presented the highest DTT responses followed by larger diesel particles, showing the importance on chemical composition and treatment factors as surfactant concentration and sonication time [167]. OP for amorphous silica NP (15 nm to $100 \mathrm{~nm}$ ) and the effects of different surface coverage of 
organic components were evaluated, finding that $15 \mathrm{~nm}$ exhibit the highest $\mathrm{OP}$ among the group [168]. Liu et al., 2020 simulated the transformation of NP in the atmosphere, evaluating the effect of coating thickness of OC and aging for $\mathrm{TiO}_{2}, \mathrm{CeO}_{2}$, and $\mathrm{SiO}_{2} \mathrm{NPs}$. Coating reduced the OP of $\mathrm{TiO}_{2}$ and $\mathrm{CeO}_{2}$ and increased the OP of $\mathrm{SiO}_{2}$; meanwhile, OP increased over $93 \%$ for all particles, due to aging by photooxidation [169]. These results suggested that there is no simple relationship between the dominant size of the air pollution particles and OP.

\section{Oxidative Potential and PM Source}

Source apportionment of estimated OP values resulting from field campaigns has shown differences among assays and sites studied, along with high temporal and spatial variability in each site. Studies conducted to date have examined the toxicity of PM collected at urban areas of interest, including locations impacted by nearby roads, airports, harbors, power plants and refineries. For example, in some studies $[149,165]$ fuel oil combustion and vehicular sources (abrasion as well as tailpipe emissions) were found to be two major contributors to ROS activity, as indicated by the association of their metallic tracers with ROS activity at Los Angeles (USA), Long Beach (USA), Beirut (Lebanon), Milan (Italy), Thessaloniki (Greece), Denver (USA) and Lahore (Pakistan). The water-soluble fraction of organic aerosols is also another major contributor to ROS activity, with a more dominant effect at the locations with higher SOA formation at Riverside (USA), Milan (Italy) and Denver (USA). Additionally, Saffari et al. found that the intrinsic PM-induced ROS activity levels, as well as the exposure to redox-active PM, are higher in locations with permissive air quality regulations compared with locations with stringent regulations [149].

Source appointment for OP estimations in Atlanta showed differences between assays. For the AA assay, the major source was vehicle emissions (brake/tire wear). Biomass burning did not contribute in the AA assay, but was the major contributor in the DTT assay [83]. This reinforced what was observed in Sarno, Italy [170], where biomass burning, and traffic emissions were the main contributors to the OP measured with the DTT assay. The contributors to the OP vary with seasonality, in Beijing the OP estimated with the DTT assay during summer and autumn was driven by vehicle emissions, in winter by coal combustion and in spring by dust emissions [71]. Major contributors in Athens, evaluated using the DCFH assay, were vehicular emissions ( $44 \%)$, secondary organic aerosol formation $(16 \%)$, and biomass burning (9\%) [71].

Land use regressions (LUR) models are being used to explain the spatial distributions and associations of the estimated OP with variables derived from geographic information systems (GIS) [171], such as traffic count/flow, population density, tree coverage, CO and NOx emissions, distance to railroads, commercial land use, parks, residential and industrial areas, distance to highways, restaurants, distance to the airport, buildings, harbors and regional background [171-176]. A study using the DTT, AA and GSH assays estimated the OP in Toronto in over 40 sampling sites and found that traffic-related components were dominant. Additionally, LUR models using the OP estimated using the AA assay performed better in summer $\left(R^{2}=0.48\right)$, while models using the OP estimated using the DTT assay performed better in winter $\left(\mathrm{R}^{2}=0.55\right)[174]$.

Previous knowledge on the relative contributions and relevance of local emission sources can be very helpful in building up the related OP values responsible for the generation of ROS. The results obtained for a sampling area must not be extrapolated to others. Therefore, OP estimations using different emission sources and size fractions are needed to help understand which PM sources could represent a significant health hazard.

\section{Final Remarks}

In summary, the OP of PM samples and their ability to generate endogenous or exogenous ROS/RNS is a relevant area of study to evaluate the toxicological and potential health effects (from damage to macromolecules in cells to increasing mortality rates). Further evaluations of the spatial 
and temporal distributions of the redox activity of PM samples are underway, along with studies of the relationship between the OP and other physical and chemical properties of PM samples.

The determination of an association between PM and particle-induced toxicity is complicated by the fact that airborne PM is composed of a complex mixture of chemicals that originates from various sources. Therefore, additional research is needed to identify the specific PM characteristics (e.g., size distribution, emission source or chemical content), which contribute the most to its redox activity. The OP measurements provide information that allows us to evaluate and integrate the toxic potential of PM samples in a unique parameter that connects emission sources, size distribution and/or chemical composition.

Finally, the OP, like a metric associated with health effects (oxidative stress), can play an important role in research associated with exposure assessment and risk management (see Figure 2). Under this conceptual scheme, the $\mathrm{OP}$ is a nexus between aspects of exposure and health impacts, since it provides information related to the dose and the biological mechanisms of the associated health effects. This improves the current knowledge and helps to establish effective pollution control and preventive strategies. Moreover, the OP can be seen as a link between the disciplines of atmospheric sciences (e.g., atmospheric chemistry), health sciences (e.g., environmental epidemiology, environmental geology, etc.) and social sciences (e.g., political sciences, economic sciences).

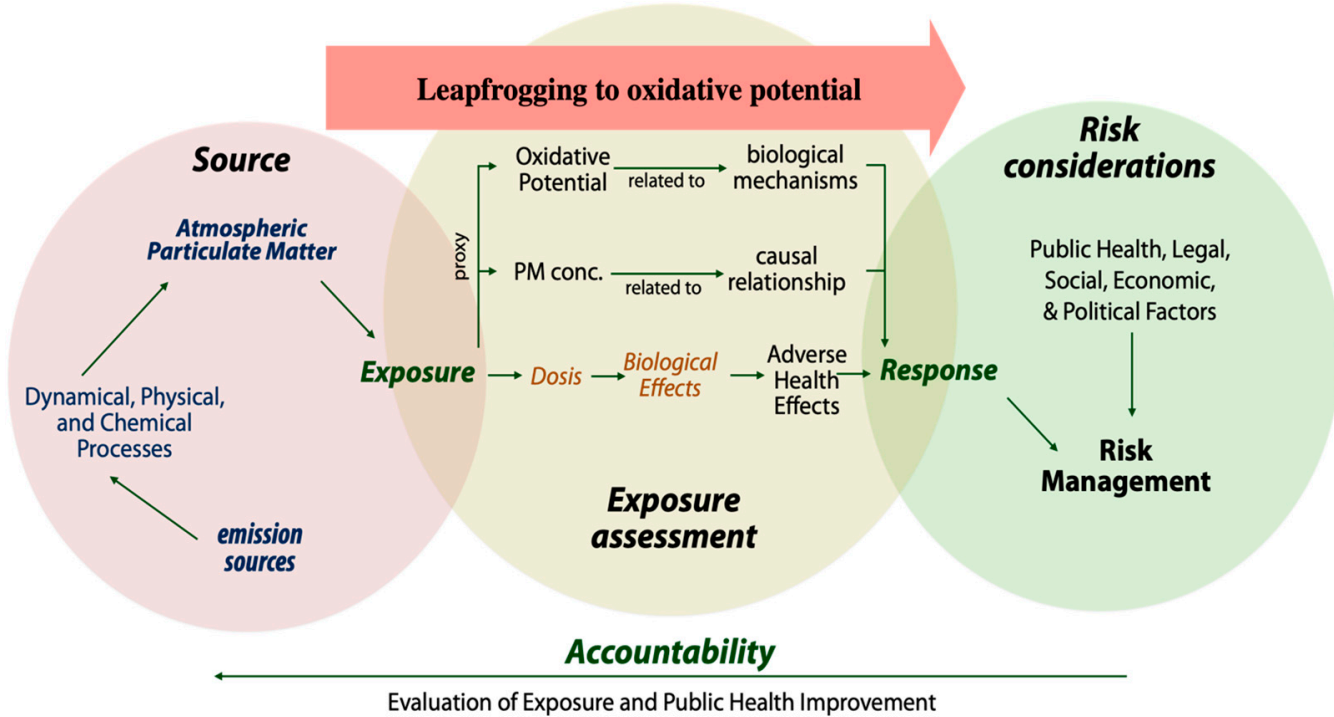

Figure 2. Conceptual an integrated research across the exposure-risk assessment-risk management.

Author Contributions: Conceptualization: M.A.L.-G.; Methodology and literature review: C.M.; Writing—original draft preparation: M.A.L.-G.; Writing—review and editing: C.M., C.A.M., R.T.A., L.M. and S.C.; Funding acquisition and Resources: M.A.L.-G.; Supervision: M.A.L.-G. All authors have read and agreed to the published version of the manuscript.

Funding: This research was funded by National Commission for Scientific and Technological Research CONICYT/FONDECYT 2016 through grant no. 1160617 and grant no. 11180151. One of the authors (C.M.) acknowledges support from National Commission for Scientific and Technological Research CONICYT: 2018 National Doctoral Scholarship Program, no. 20181015. The funders had no role in the study design, data collection and analysis, decision to publish or the preparation of the manuscript.

Conflicts of Interest: The authors declare no conflict of interest.

\section{References}

1. UN, United Nations, Department of Economic and Social Affairs. World Urbanization Prospects, The 2018 Revision 2018. 2018. Available online: https://population.un.org/wup/Publications/Files/WUP2018-Report. pdf (accessed on 29 May 2020). 
2. Anderson, J.O.; Thundiyil, J.G.; Stolbach, A. Clearing the Air: A Review of the Effects of Particulate Matter Air Pollution on Human Health. J. Med. Toxicol. 2012, 8, 166-175. [CrossRef]

3. Kim, K.-H.; Kabir, E.; Kabir, S. A Review on the Human Health Impact of Airborne Particulate Matter. Environ. Int. 2015, 74, 136-143. [CrossRef]

4. Landrigan, P.J.; Fuller, R.; Acosta, N.J.R.; Adeyi, O.; Arnold, R.; Basu, N.; Baldé, A.B.; Bertollini, R.; Bose-O'Reilly, S.; Boufford, J.I.; et al. The Lancet Commission on Pollution and Health. Lancet 2018, 391, 462-512. [CrossRef]

5. Dockery, D.W. Health Effects of Particulate Air Pollution. Ann. Epidemiol. 2009, 19, 257-263. [CrossRef]

6. IARC. International Agency for Research on Cancer Press Release $N^{\circ} 221$ IARC: Outdoor Air Pollution a Leading Environmental Cause of Cancer Deaths. 2013. Available online: https://www.iarc.fr/wp-content/ uploads/2018/07/pr221_E.pdf (accessed on 29 May 2020).

7. Yang, B.Y.; Qian, Z.M.; Li, S.; Chen, G.; Bloom, M.S.; Elliott, M.; Syberg, K.W.; Heinrich, J.; Markevych, I.; Wang, S.Q.; et al. Ambient Air Pollution in Relation to Diabetes and Glucose-Homoeostasis Markers in China: A Cross-Sectional Study with Findings from the 33 Communities Chinese Health Study. Lancet Planet. Health 2018, 2, e64-e73. [CrossRef]

8. Li, Z.; Wen, Q.; Zhang, R. Sources, Health Effects and Control Strategies of Indoor Fine Particulate Matter (PM2.5): A Review. Sci. Total Environ. 2017, 586, 610-622. [CrossRef]

9. Li, M.H.; Fan, L.C.; Mao, B.; Yang, J.W.; Choi, A.M.K.; Cao, W.J.; Xu, J.F. Short-Term Exposure to Ambient Fine Particulate Matter Increases Hospitalizations and Mortality in COPD: A Systematic Review and Meta-Analysis. Chest 2016, 149, 447-458. [CrossRef]

10. Fu, P.; Guo, X.; Cheung, F.M.H.; Yung, K.K.L. The Association between PM 2.5 Exposure and Neurological Disorders: A Systematic Review and Meta-Analysis. Sci. Total Environ. 2019, 10, 1240-1248. [CrossRef]

11. Zhang, H.; Li, S.; Chen, G.; Abdulai, T.; Liu, X.; Wang, Y.; Liang, H.; Hou, J.; Huo, W.; Mao, Z.; et al. Ambient Air Pollutants Aggravate Association of Snoring with Prevalent Hypertension: Results from the Henan Rural Cohort. Chemosphere 2020, 256, 127108. [CrossRef]

12. Ostro, B. The Association of Air Pollution and Mortality Examining the Case for Inference. Arch. Environ. Health 1993, 48, 336-342. [CrossRef]

13. Shiraiwa, M.; Ueda, K.; Pozzer, A.; Lammel, G.; Kampf, C.J.; Fushimi, A.; Enami, S.; Arangio, A.M.; Fröhlich-Nowoisky, J.; Fujitani, Y.; et al. Aerosol Health Effects from Molecular to Global Scales. Environ. Sci. Technol. 2017, 51, 13545-13567. [CrossRef]

14. Chen, R.; Hu, B.; Liu, Y.; Xu, J.; Yang, G.; Xu, D.; Chen, C. Beyond PM2.5: The Role of Ultrafine Particles on Adverse Health Effects of Air Pollution. Biochim. Biophys. 2016, 1860, 2844-2855. [CrossRef]

15. Incecik, S.; Gertler, A.; Kassomenos, P. Aerosols and Air Quality. Sci. Total Environ. 2014, 488, 488-489. [CrossRef]

16. Mcdonald, K. Air Pollution in the Urban Atmosphere: Sources and Consequences. In Metropolitan Sustainability. Understanding and Improving the Urban Environment; Woodhead Publishing: Amsterdam, The Netherlands, 2012; pp. 231-259.

17. Xing, Y.F.; Xu, Y.H.; Shi, M.H.; Lian, Y.X. The Impact of PM2.5 on the Human Respiratory System. J. Thorac. Dis. 2016, 8, E69-E74.

18. Di, Q.; Dai, L.; Wang, Y.; Zanobetti, A.; Choirat, C.; Schwartz, J.D.; Dominici, F. Association of Short-Term Exposure to Air Pollution with Mortality in Older Adults. JAMA J. Am. Med. Assoc. 2017, 318, 2446-2456. [CrossRef]

19. Malley, C.S.; Kuylenstierna, J.C.I.; Vallack, H.W.; Henze, D.K.; Blencowe, H.; Ashmore, M.R. Preterm Birth Associated with Maternal Fine Particulate Matter Exposure: A Global, Regional and National Assessment. Environ. Int. 2017, 101, 173-182. [CrossRef]

20. Mortamais, M.; Pujol, J.; Martínez-Vilavella, G.; Fenoll, R.; Reynes, C.; Sabatier, R.; Rivas, I.; Forns, J.; Vilor-Tejedor, N.; Alemany, S.; et al. Effects of Prenatal Exposure to Particulate Matter Air Pollution on Corpus Callosum and Behavioral Problems in Children. Environ. Res. 2019, 178, 108734. [CrossRef]

21. Deng, Q.; Deng, L.; Miao, Y.; Guo, X.; Li, Y. Particle Deposition in the Human Lung: Health Implications of Particulate Matter from Different Sources. Environ. Res. 2019, 169, 237-245. [CrossRef]

22. USEPA. Regulatory Impact Analyses for the Particulate Matter and Ozone National Ambient Air Quality Standards and Proposed Regional Haze Rule; United States Environmental Protection Agency, Office of Air Quality Planning and Standards, Research Triangle Park: Washington, DC, USA, 1996; Appendix A-2; pp. A-7-A-8. 
23. Shi, L.; Zanobetti, A.; Kloog, I.; Coull, B.A.; Koutrakis, P.; Melly, S.J.; Schwartz, J.D. Low-Concentration PM2.5 and Mortality: Estimating Acute and Chronic Effects in a Population-Based Study. Environ. Health Perspect. 2016, 124, 46-52. [CrossRef]

24. Saliba, N. A Comparative Review of PM Levels, Sources, and Their Likely Fates in the Eastern Mediterranean Region. In Urban Airborne Particulate Matter: Origin, Chemistry, Fate, and Health Impacts; Zereini, F., Wiseman, C.L.S., Eds.; Springer: Heidelberg, Germany; New York, NY, USA, 2010; pp. 3-17.

25. Arhami, M.; Hosseini, V.; Zare Shahne, M.; Bigdeli, M.; Lai, A.; Schauer, J.J. Seasonal Trends, Chemical Speciation and Source Apportionment of Fine PM in Tehran. Atmos. Environ. 2017, 153, 70-82. [CrossRef]

26. Snider, G.; Weagle, C.L.; Murdymootoo, K.K.; Ring, A.; Ritchie, Y.; Stone, E.; Walsh, A.; Akoshile, C.; Anh, N.X.; Balasubramanian, R.; et al. Variation in Global Chemical Composition of PM2.5: Emerging Results from SPARTAN. Atmos. Chem. Phys. 2016, 16, 9629-9653. [CrossRef]

27. Amato, F.; Alastuey, A.; Karanasiou, A.; Lucarelli, F.; Nava, S.; Calzolai, G.; Severi, M.; Becagli, S.; Gianelle, V.L.; Colombi, C.; et al. AIRUSE-LIFE+: A Harmonized PM Speciation and Source Apportionment in Five Southern European Cities. Atmos. Chem. Phys. 2016, 16, 3289-3309. [CrossRef]

28. Tao, J.; Zhang, L.; Cao, J.; Zhang, R. A Review of Current Knowledge Concerning PM2.5 Chemical Composition, Aerosol Optical Properties and Their Relationships across China. Atmos. Chem. Phys. 2017, 17, 9485-9518. [CrossRef]

29. Wei, K.; Zou, Z.; Zheng, Y.; Li, J.; Shen, F.; Wu, C.Y.; Wu, Y.; Hu, M.; Yao, M. Ambient Bioaerosol Particle Dynamics Observed during Haze and Sunny Days in Beijing. Sci. Total Environ. 2016, 550, 751-759. [CrossRef]

30. Kelly, F.J.; Fussell, J.C. Size, Source and Chemical Composition as Determinants of Toxicity Attributable to Ambient Particulate Matter. Atmos. Environ. 2012, 60, 504-526. [CrossRef]

31. Kim, K.H.; Jahan, S.A.; Kabir, E.; Brown, R.J. Review of Airborne Polycyclic Aromatic Hydrocarbons (PAHs) and Their Human Health Effects. Environ. Int. 2013, 60, 71-80. [CrossRef]

32. Adams, K.; Greenbaum, D.S.; Shaikh, R.; van Erp, A.M.; Russell, A.G. Particulate Matter Components, Sources, and Health: Systematic Approaches to Testing Effects. J. Air Waste Manag. Assoc. 2015, 65, 544-558. [CrossRef]

33. Levy, J.I.; Diez, D.; Dou, Y.; Barr, C.D.; Dominici, F. A Meta-Analysis and Multisite Time-Series Analysis of the Differential Toxicity of Major Fine Particulate Matter Constituents. Am. J. Epidemiol. 2012, 175, 1091-1099. [CrossRef]

34. Bell, M.L. Assessment of the Health Impacts of Particulate Matter Characteristics. Res. Rep. Health Eff. Inst. 2012, 161, 5-38.

35. Bernard, A. Cadmium \& Its Adverse Effects on Human Health. Indian J. Med. Res. 2008, 128, 557-564.

36. White, A.J.; O’Brien, K.M.; Niehoff, N.M.; Carroll, R.; Sandler, D.P. Metallic Air Pollutants and Breast Cancer Risk in a Nationwide Cohort Study. Epidemiology 2019, 30, 20-28. [CrossRef]

37. Bouwmeester, H.; Lynch, I.; Marvin, H.J.P.; Dawson, K.A.; Berges, M.; Braguer, D.; Byrne, H.J.; Casey, A.; Chambers, G.; Clift, M.J.D.; et al. Minimal Analytical Characterization of Engineered Nanomaterials Needed for Hazard Assessment in Biological Matrices. Nanotoxicology 2011, 5, 1-11. [CrossRef]

38. Wilson, $\mathrm{W}$. The exposure paradox in particulate matter community time-series epidemiology: Can ambient concentrations of PM be used as a surrogate for personal exposure to PM? Epidemiology 2001, 12, S67.

39. Hellack, B.; Nickel, C.; Albrecht, C.; Kuhlbusch, T.A.J.; Boland, S.; Baeza-Squiban, A.; Wohlleben, W.; Schins, R.P.F. Analytical Methods to Assess the Oxidative Potential of Nanoparticles: A Review. Environ. Sci. Nano 2017, 4, 1920-1934. [CrossRef]

40. Kelly, F.J.; Fuller, G.W.; Walton, H.A.; Fussell, J.C. Monitoring Air Pollution: Use of Early Warning Systems for Public Health. Respirology 2012, 17, 7-19. [CrossRef]

41. Ricci, P.F.; Cirillo, M.C. Uncertainty in Health Risk Analysis. J. Hazard. Mater. 1985, 10, 433-447. [CrossRef]

42. WHO. Review of Evidence on Health Aspects of Air Pollution-REVIHAAP; First Results; World Health Organization, Regional Office for Europe: Copenhagen, Denmark, 2013. Available online: https://bit.ly/ 2KOhOMx (accessed on 29 May 2020).

43. Miranda, A.I.; Valente, J.; Costa, A.M.; Lopes, M.; Borrego, C. Current Environmental Issues and Challenges. Air Pollution and Health Effects; Springer: Dordrecht, The Netherlands, 2014; pp. 1-13.

44. Rohr, A.C.; Wyzga, R.E. Attributing Health Effects to Individual Particulate Matter Constituents. Atmos. Environ. 2012, 62, 130-152. [CrossRef] 
45. Yang, W.; Omaye, S.T. Air Pollutants, Oxidative Stress and Human Health. Mutat. Res. Genet. Toxicol. Environ. 2009, 674, 45-54. [CrossRef]

46. Øvrevik, J.; Refsnes, M.; Låg, M.; Holme, J.; Schwarze, P. Activation of Proinflammatory Responses in Cells of the Airway Mucosa by Particulate Matter: Oxidant- and Non-Oxidant-Mediated Triggering Mechanisms. Biomolecules 2015, 5, 1399-1440. [CrossRef]

47. Darbre, P.D. Overview of Air Pollution and Endocrine Disorders. Int. J. Gen. Med. 2018, 11, $191-207$. [CrossRef]

48. Delfino, R.J.; Staimer, N.; Tjoa, T.; Gillen, D.L.; Schauer, J.J.; Shafer, M.M. Airway Inflammation and Oxidative Potential of Air Pollutant Particles in a Pediatric Asthma Panel. J. Expos. Sci. Environ. Epidemiol. 2013, 23, 466-473. [CrossRef]

49. Hoek, G.; Krishnan, R.M.; Beelen, R.; Peters, A.; Ostro, B.; Brunekreef, B.; Kaufman, J.D. Long-Term Air Pollution Exposure and Cardio-Respiratory Mortality: A Review. Environ. Health 2013, 12, 12-43. [CrossRef]

50. Li, Q.; Wyatt, A.; Kamens, R.M. Oxidant Generation and Toxicity Enhancement of Aged-Diesel Exhaust. Atmos. Environ. 2009, 43, 1037-1042. [CrossRef]

51. Lin, P.; Yu, J.Z. Generation of Reactive Oxygen Species Mediated by Humic-like Substances in Atmospheric Aerosols. Environ. Sci. Technol. 2011, 45, 10362-10368. [CrossRef]

52. Valavanidis, A.; Vlachogianni, T.; Fiotakis, K.; Loridas, S. Pulmonary Oxidative Stress, Inflammation and Cancer: Respirable Particulate Matter, Fibrous Dusts and Ozone as Major Causes of Lung Carcinogenesis through Reactive Oxygen Species Mechanisms. Int. J. Environ. Res. Public Health 2013, 10, 3886-3907. [CrossRef]

53. Clift, M.J.D.; Rothen-Rutishauser, B. Studying the Oxidative Stress Paradigm In Vitro: A Theoretical and Practical Perspective. Methods Mol. Biol. 2013, 1028, 115-133.

54. Charrier, J.G.; Anastasio, C. Impacts of Antioxidants on Hydroxyl Radical Production from Individual and Mixed Transition Metals in a Surrogate Lung Fluid. Atmos. Environ. 2011, 45, 7555-7562. [CrossRef]

55. Jiang, H.; Ahmed, C.M.S.; Canchola, A.; Chen, J.Y.; Lin, Y.-H. Use of Dithiothreitol Assay to Evaluate the Oxidative Potential of Atmospheric Aerosols. Atmosphere 2019, 10, 571. [CrossRef]

56. Frezzini, M.A.; Castellani, F.; De Francesco, N.; Ristorini, M.; Canepari, S. Application of DPPH Assay for Assessment of Particulate Matter Reducing Properties. Atmosphere 2019, 10, 816. [CrossRef]

57. Tuet, W.Y.; Fok, S.; Verma, V.; Tagle Rodriguez, M.S.; Grosberg, A.; Champion, J.A.; Ng, N.L. Dose-Dependent Intracellular Reactive Oxygen and Nitrogen Species (ROS/RNS) Production from Particulate Matter Exposure: Comparison to Oxidative Potential and Chemical Composition. Atmos. Environ. 2016, 144, 335-344. [CrossRef]

58. Arnhold, J. Chapter 2-Role of Reactive Species in Destructions. In Cell and Tissue Destruction: Mechanisms, Protection, Disorders; Academic Press: Cambridge, MA, USA, 2020; pp. 23-54. [CrossRef]

59. Di Meo, S.; Reed, T.T.; Venditti, P.; Victor, V.M. Role of ROS and RNS Sources in Physiological and Pathological Conditions. Oxid. Med. Cell. Longev. 2016, 2016, 44. [CrossRef] [PubMed]

60. Chio, C.P.; Chen, S.C.; Chiang, K.C.; Chou, W.C.; Liao, C.M. Oxidative Stress Risk Analysis for Exposure to Diesel Exhaust Particle-Induced Reactive Oxygen Species. Sci. Total Environ. 2007, 387, 113-127. [CrossRef] [PubMed]

61. Venkatachari, P.; Hopke, P.K.; Brune, W.H.; Ren, X.; Lesher, R.; Mao, J.; Mitchel, M. Characterization of Wintertime Reactive Oxygen Species Concentrations in Flushing, New York. Aerosol Sci. Technol. 2007, 41, 97-111. [CrossRef]

62. Zhang, Y.; Schauer, J.J.; Shafer, M.M.; Hannigan, M.P.; Dutton, S.J. Source Apportionment of in Vitro Reactive Oxygen Species Bioassay Activity from Atmospheric Particulate Matter. Environ. Sci. Technol. 2008, 42, 7502-7509. [CrossRef]

63. Øvrevik, J. Oxidative Potential versus Biological Effects: A Review on the Relevance of Cell-Free/Abiotic Assays as Predictors of Toxicity from Airborne Particulate Matter. Int. J. Mol. Sci. 2019, 20, 4772. [CrossRef]

64. Cho, A.K.; Sioutas, C.; Miguel, A.H.; Kumagai, Y.; Schmitz, D.A.; Singh, M.; Eiguren-Fernandez, A.; Froines, J.R. Redox Activity of Airborne Particulate Matter at Different Sites in the Los Angeles Basin. Environ. Res. 2005, 99, 40-47. [CrossRef]

65. Charrier, J.G.; Anastasio, C. On Dithiothreitol (DTT) as a Measure of Oxidative Potential for Ambient Particles: Evidence for the Importance of Soluble Transition Metals. Atmos. Chem. Phys. 2012, 12, 11317-11350. [CrossRef]

66. Molina, C.; Andrade, C.; Manzano, C.A.; Richard Toro, A.; Verma, V.; Leiva-Guzmán, M.A. Dithiothreitol-Based Oxidative Potential for Airborne Particulate Matter: An Estimation of the Associated Uncertainty. Environ. Sci. Pollut. Res. 2020, 27, 29672-29680. [CrossRef] 
67. Pietrogrande, M.C.; Bertoli, I.; Manarini, F.; Russo, M. Ascorbate Assay as a Measure of Oxidative Potential for Ambient Particles: Evidence for the Importance of Cell-Free Surrogate Lung Fluid Composition. Atmos. Environ. 2019, 211, 103-112. [CrossRef]

68. Kurmi, O.P.; Dunster, C.; Ayres, J.G.; Kelly, F.J. Oxidative Potential of Smoke from Burning Wood and Mixed Biomass Fuels. Free Radic. Res. 2013, 47, 829-835. [CrossRef]

69. Godri, K.J.; Harrison, R.M.; Evans, T.; Baker, T.; Dunster, C.; Mudway, I.S.; Kelly, F.J. Increased Oxidative Burden Associated with Traffic Component of Ambient Particulate Matter at Roadside and Urban Background Schools Sites in London. PLoS ONE 2011, 6, e21961. [CrossRef] [PubMed]

70. Jovanovic, M.V.; Savic, J.Z.; Salimi, F.; Stevanovic, S.; Bottle, S.; Ristovski, Z.D. Measurements of Oxidative Potential of Particulate Matter at Belgrade Tunnel; Comparison of BPEAnit, DTT and DCFH Assays. Int. J. Environ. Res. Public Health 2019, 16, 4906. [CrossRef] [PubMed]

71. Taghvaee, S.; Sowlat, M.H.; Diapouli, E.; Manousakas, M.I.; Vasilatou, V.; Eleftheriadis, K.; Sioutas, C. Source Apportionment of the Oxidative Potential of Fine Ambient Particulate Matter (PM2.5) in Athens, Greece. Sci. Total Environ. 2019, 653, 1407-1416. [CrossRef] [PubMed]

72. Janssen, N.A.H.; Strak, M.; Yang, A.; Hellack, B.; Kelly, F.J.; Kuhlbusch, T.A.J.; Harrison, R.M.; Brunekreef, B.; Cassee, F.R.; Steenhof, M.; et al. Associations between Three Specific A-Cellular Measures of the Oxidative Potential of Particulate Matter and Markers of Acute Airway and Nasal Inflammation in Healthy Volunteers. Occup. Environ. Med. 2015, 72, 49-56. [CrossRef]

73. Hogervorst, J.G.F.; De Kok, T.M.C.M.; Briedé, J.J.; Wesseling, G.; Kleinjans, J.C.S.; Van Schayck, C.P. Relationship between Radical Generation by Urban Ambient Particulate Matter and Pulmonary Function of School Children. J. Toxicol. Environ. Health Part A 2006, 69, 245-262. [CrossRef]

74. Bates, J.T.; Fang, T.; Verma, V.; Zeng, L.; Weber, R.J.; Tolbert, P.E.; Abrams, J.Y.; Sarnat, S.E.; Klein, M.; Mulholland, J.A.; et al. Review of Acellular Assays of Ambient Particulate Matter Oxidative Potential: Methods and Relationships with Composition, Sources, and Health Effects. Environ. Sci. Technol. 2019, 53, 4003-4019. [CrossRef]

75. Hedayat, F.; Stevanovic, S.; Miljevic, B.; Bottle, S.; Ristovski, Z.D. Review-Evaluating the Molecular Assays for Measuring the Oxidative Potential of Particulate Matter. Chem. Ind. Chem. Eng. Q. 2015, 21, 201-210. [CrossRef]

76. Piacentini, D.; Falasca, G.; Canepari, S.; Massimi, L. Potential of PM-Selected Components to Induce Oxidative Stress and Root System Alteration in a Plant Model Organism. Environ. Int. 2019, 132, 105094. [CrossRef]

77. Simonetti, G.; Conte, E.; Perrino, C.; Canepari, S. Oxidative Potential of Size-Segregated PM in an Urban and an Industrial Area of Italy. Atmos. Environ. 2018, 187, 292-300. [CrossRef]

78. Manigrasso, M.; Simonetti, G.; Astolfi, M.L.; Perrino, C.; Canepari, S.; Protano, C.; Antonucci, A.; Avino, P.; Vitali, M. Oxidative Potential Associated with Urban Aerosol Deposited into the Respiratory System and Relevant Elemental and Ionic Fraction Contributions. Atmosphere 2020, 11, 6. [CrossRef]

79. Gao, D.; Godri Pollitt, K.J.; Mulholland, J.A.; Russell, A.G.; Weber, R.J. Characterization and Comparison of PM2.5 Oxidative Potential Assessed by Two Acellular Assays. Atmos. Chem. Phys. 2020, 20, 5197-5210. [CrossRef]

80. Abrams, J.Y.; Weber, R.J.; Klein, M.; Samat, S.E.; Chang, H.H.; Strickland, M.J.; Verma, V.; Fang, T.; Bates, J.T.; Mulholland, J.A.; et al. Associations between Ambient Fine Particulate Oxidative Potential and Cardiorespiratory Emergency Department Visits. Environ. Health Perspect. 2017, 125, 10.

81. Yang, A.; Janssen, N.A.H.; Brunekreef, B.; Cassee, F.R.; Hoek, G.; Gehring, U. Children's Respiratory Health and Oxidative Potential of PM2.5: The PIAMA Birth Cohort Study. Occup. Environ. Med. 2016, 73, 154-160. [CrossRef] [PubMed]

82. Weichenthal, S.; Crouse, D.L.; Pinault, L.; Godri-Pollitt, K.; Lavigne, E.; Evans, G.; van Donkelaar, A.; Martin, R.V.; Burnett, R.T. Oxidative Burden of Fine Particulate Air Pollution and Risk of Cause-Specific Mortality in the Canadian Census Health and Environment Cohort (CanCHEC). Environ. Res. 2016, 146, 92-99. [CrossRef] [PubMed]

83. Fang, T.; Verma, V.; Bates, J.T.; Abrams, J.; Klein, M.; Strickland, J.M.; Sarnat, E.S.; Chang, H.H.; Mulholland, A.J.; Tolbert, E.P.; et al. Oxidative Potential of Ambient Water-Soluble PM2.5 in the Southeastern United States: Contrasts in Sources and Health Associations between Ascorbic Acid (AA) and Dithiothreitol (DTT) Assays. Atmos. Chem. Phys. 2016, 16, 3865-3879. [CrossRef] 
84. Fu, H.; Liu, X.; Li, W.; Zu, Y.; Zhou, F.; Shou, Q.; Ding, Z. PM2.5 Exposure Induces Inflammatory Response in Macrophages via the TLR4/COX-2/NF-KB Pathway. Inflammation 2020, 6, 1-11.

85. Figliuzzi, M.; Tironi, M.; Longaretti, L.; Mancini, A.; Teoldi, F.; Sangalli, F.; Remuzzi, A. Copper-Dependent Biological Effects of Particulate Matter Produced by Brake Systems on Lung Alveolar Cells. Arch. Toxicol. 2020, 94, 2965-2979. [CrossRef]

86. MohseniBandpi, A.; Eslami, A.; Shahsavani, A.; Khodagholi, F.; Alinejad, A. Physicochemical Characterization of Ambient PM2.5 in Tehran Air and Its Potential Cytotoxicity in Human Lung Epithelial Cells (A549). Sci. Total Environ. 2017, 593-594, 182-190. [CrossRef]

87. Yang, L.; Liu, G.; Lin, Z.; Wang, Y.; He, H.; Liu, T.; Kamp, D.W. Pro-Inflammatory Response and Oxidative Stress Induced by Specific Components in Ambient Particulate Matter in Human Bronchial Epithelial Cells. Environ. Toxicol. 2016, 31, 923-936. [CrossRef]

88. Vaughan, A.; Stevanovic, S.; Banks, A.P.W.; Zare, A.; Rahman, M.M.; Bowman, R.V.; Fong, K.M.; Ristovski, Z.D.; Yang, I.A. The Cytotoxic, Inflammatory and Oxidative Potential of Coconut Oil-Substituted Diesel Emissions on Bronchial Epithelial Cells at an Air-Liquid Interface. Environ. Sci. Pollut. Res. 2019, 26, 27783-27791. [CrossRef]

89. Ndong Ba, A.; Cazier, F.; Verdin, A.; Garcon, G.; Cabral, M.; Courcot, L.; Diouf, A.; Courcot, D.; Gualtieri, M.; Fall, M. Physico-Chemical Characterization and in Vitro Inflammatory and Oxidative Potency of Atmospheric Particles Collected in Dakar City's (Senegal). Environ. Pollut. 2019, 245, 568-581. [CrossRef]

90. Xu, Z.; Wu, H.; Zhang, H.; Bai, J.; Zhang, Z. Interleukins 6/8 and Cyclooxygenase-2 Release and Expressions Are Regulated by Oxidative Stress-JAK2/STAT3 Signaling Pathway in Human Bronchial Epithelial Cells Exposed to Particulate Matter $\leq 2.5$ Mm. J. Appl. Toxicol. 2020, 40, 1210-1218. [CrossRef] [PubMed]

91. Li, Y.; Yang, M.; Meng, T.; Niu, Y.; Dai, Y.; Zhang, L.; Zheng, X.; Jalava, P.; Dong, G.; Gao, W.; et al. Oxidative Stress Induced by Ultrafine Carbon Black Particles Can Elicit Apoptosis in Vivo and Vitro. Sci. Total Environ. 2020, 709, 135802. [CrossRef] [PubMed]

92. Mantecca, P.; Sancini, G.; Moschini, E.; Farina, F.; Gualtieri, M.; Rohr, A.; Miserocchi, G.; Palestini, P.; Camatini, M. Lung Toxicity Induced by Intratracheal Instillation of Size-Fractionated Tire Particles. Toxicol. Lett. 2009, 189, 206-214. [CrossRef] [PubMed]

93. Jiang, H.; Jang, M.; Sabo-Attwood, T.; Robinson, S.E. Oxidative Potential of Secondary Organic Aerosols Produced from Photooxidation of Different Hydrocarbons Using Outdoor Chamber under Ambient Sunlight. Atmos. Environ. 2016, 131, 382-389. [CrossRef]

94. Xu, C.; Zhang, M.; Chen, W.; Jiang, L.; Chen, C.; Qin, J. Assessment of Air Pollutant PM2.5 Pulmonary Exposure Using a 3D Lung-on-Chip Model. ACS Biomater. Sci. Eng. 2020, 6, 3081-3090. [CrossRef]

95. Yang, J.W.; Shen, Y.C.; Lin, K.C.; Cheng, S.J.; Chen, S.L.; Chen, C.Y.; Kumar, P.V.; Lin, S.F.; Lu, H.E.; Chen, G.Y. Organ-on-a-Chip: Opportunities for Assessing the Toxicity of Particulate Matter. Front. Bioeng. Biotechnol. 2020, 8, 519. [CrossRef]

96. Mauriac, H.; Pannetier, C.; Velvé Casquillas, G. Organs on Chip Review-Elveflow. 2017. Available online: https://www.elveflow.com/microfluidic-reviews/organs-on-chip-3d-cell-culture/organs-chip-review/ (accessed on 13 August 2020).

97. Li, Y.; Hu, C.; Wang, P.; Liu, Y.; Wang, L.; Pi, Q.; Gong, Z.; Yang, X.; Mak, M.; Wu, Y. Indoor Nanoscale Particulate Matter-Induced Coagulation Abnormality Based on a Human 3D Microvascular Model on a Microfluidic Chip. J. Nanobiotechnol. 2019, 17, 20. [CrossRef]

98. Møller, P.; Loft, S. Oxidative Damage to DNA and Lipids as Biomarkers of Exposure to Air Pollution. Environ. Health Perspect. 2010, 118, 1126-1136. [CrossRef]

99. Zhang, X.; Staimer, N.; Gillen, D.L.; Tjoa, T.; Schauer, J.J.; Shafer, M.M.; Hasheminassab, S.; Pakbin, P.; Vaziri, N.D.; Sioutas, C.; et al. Associations of Oxidative Stress and Inflammatory Biomarkers with Chemically-Characterized Air Pollutant Exposures in an Elderly Cohort. Environ. Res. 2016, 150, 306-319. [CrossRef]

100. Strak, M.; Janssen, N.A.H.; Godri, K.J.; Gosens, I.; Mudway, I.S.; Cassee, F.R.; Lebret, E.; Kelly, F.J.; Harrison, R.M.; Brunekreef, B.; et al. Respiratory Health Effects of Airborne Particulate Matter: The Role of Particle Size, Composition, and Oxidative Potential-the RAPTES Project. Environ. Health Perspect. 2012, 120, 1183-1189. [CrossRef] [PubMed] 
101. Borm, P.J.A.; Kelly, F.; Künzli, N.; Schins, R.P.F.; Donaldson, K. Oxidant Generation by Particulate Matter: From Biologically Effective Dose to a Promising, Novel Metric. Occup. Environ. Med. 2007, 64, 73-74. [CrossRef] [PubMed]

102. Verma, V.; Pakbin, P.; Cheung, K.L.; Cho, A.K.; Schauer, J.J.; Shafer, M.M.; Kleinman, M.T.; Sioutas, C. Physicochemical and Oxidative Characteristics of Semi-Volatile Components of Quasi-Ultrafine Particles in an Urban Atmosphere. Atmos. Environ. 2011, 45, 1025-1033. [CrossRef]

103. Daher, N.; Ning, Z.; Cho, A.K.; Shafer, M.; Schauer, J.J.; Sioutas, C. Comparison of the Chemical and Oxidative Characteristics of Particulate Matter (PM) Collected by Different Methods: Filters, Impactors, and BioSamplers. Aerosol Sci. Technol. 2011, 45, 1294-1304. [CrossRef]

104. Wang, D.; Pakbin, P.; Shafer, M.M.; Antkiewicz, D.; Schauer, J.J.; Sioutas, C. Macrophage Reactive Oxygen Species Activity of Water-Soluble and Water-Insoluble Fractions of Ambient Coarse, PM2.5 and Ultrafine Particulate Matter (PM) in Los Angeles. Atmos. Environ. 2013, 77, 301-310. [CrossRef]

105. Guo, H.B.; Li, M.; Lyu, Y.; Cheng, T.T.; Xv, J.J.; Li, X. Size-Resolved Particle Oxidative Potential in the Office, Laboratory, and Home: Evidence for the Importance of Water-Soluble Transition Metals. Environ. Pollut. 2019, 246, 704-709. [CrossRef]

106. Calas, A.; Uzu, G.; Kelly, F.J.; Houdier, S.; Martins, J.M.F.; Thomas, F.; Molton, F.; Charron, A.; Dunster, C.; Oliete, A.; et al. Comparison between Five Acellular Oxidative Potential Measurement Assays Performed with Detailed Chemistry on PM10 Samples from the City of Chamonix (France). Atmos. Chem. Phys. 2018, 18, 7863-7875. [CrossRef]

107. Liu, W.J.; Xu, Y.S.; Liu, W.X.; Liu, Q.Y.; Yu, S.Y.; Liu, Y.; Wang, X.; Tao, S. Oxidative Potential of Ambient PM2.5in the Coastal Cities of the Bohai Sea, Northern China: Seasonal Variation and Source Apportionment. Environ. Pollut. 2018, 236, 514-528. [CrossRef]

108. Gao, D.; Mulholland, J.A.; Russell, A.G.; Weber, R.J. Characterization of Water-Insoluble Oxidative Potential of PM2.5 Using the Dithiothreitol Assay. Atmos. Environ. 2020, 224, 117327. [CrossRef]

109. Yu, S.; Liu, W.; Xu, Y.; Yi, K.; Zhou, M.; Tao, S.; Liu, W. Characteristics and Oxidative Potential of Atmospheric PM2.5 in Beijing: Source Apportionment and Seasonal Variation. Sci. Total Environ. 2019, 650, $277-287$. [CrossRef]

110. Shao, L.; Hu, Y.; Shen, R.; Schäfer, K.; Wang, J.; Wang, J.; Schnelle-Kreis, J.; Zimmermann, R.; BéruBé, K.; Suppan, P. Seasonal Variation of Particle-Induced Oxidative Potential of Airborne Particulate Matter in Beijing. Sci. Total Environ. 2017, 579, 1152-1160. [CrossRef] [PubMed]

111. Perrone, M.R.; Bertoli, I.; Romano, S.; Russo, M.; Rispoli, G.; Pietrogrande, M.C. PM2.5 and PM10 Oxidative Potential at a Central Mediterranean Site: Contrasts between Dithiothreitol- and Ascorbic Acid-Measured Values in Relation with Particle Size and Chemical Composition. Atmos. Environ. 2019, 210, 143-155. [CrossRef]

112. Paraskevopoulou, D.; Bougiatioti, A.; Stavroulas, I.; Fang, T.; Lianou, M.; Liakakou, E.; Gerasopoulos, E.; Weber, R.; Nenes, A.; Mihalopoulos, N. Yearlong Variability of Oxidative Potential of Particulate Matter in an Urban Mediterranean Environment. Atmos. Environ. 2019, 206, 183-196. [CrossRef]

113. Chen, Q.; Wang, M.; Wang, Y.; Zhang, L.; Li, Y.; Han, Y. Oxidative Potential of Water-Soluble Matter Associated with Chromophoric Substances in PM 2.5 over Xi'an, China. Environ. Sci. Technol. 2019, 53, 8574-8584. [CrossRef]

114. Wang, J.; Lin, X.; Lu, L.; Wu, Y.; Zhang, H.; Lv, Q.; Liu, W.; Zhang, Y.; Zhuang, S. Temporal Variation of Oxidative Potential of Water Soluble Components of Ambient PM2.5 Measured by Dithiothreitol (DTT) Assay. Sci. Total Environ. 2019, 649, 969-978. [CrossRef]

115. Janssen, N.A.H.; Yang, A.; Strak, M.; Steenhof, M.; Hellack, B.; Gerlofs-Nijland, M.E.; Kuhlbusch, T.; Kelly, F.; Harrison, R.; Brunekreef, B.; et al. Oxidative Potential of Particulate Matter Collected at Sites with Different Source Characteristics. Sci. Total Environ. 2014, 472, 572-581. [CrossRef]

116. Boogaard, H.; Janssen, N.A.H.; Fischer, P.H.; Kos, G.P.A.; Weijers, E.P.; Cassee, F.R.; van der Zee, S.C.; de Hartog, J.J.; Brunekreef, B.; Hoek, G. Contrasts in Oxidative Potential and Other Particulate Matter Characteristics Collected near Major Streets and Background Locations. Environ. Health Perspect. 2012, 120, 185-191. [CrossRef]

117. Ntziachristos, L.; Froines, J.R.; Cho, A.K.; Sioutas, C. Relationship between Redox Activity and Chemical Speciation of Size-Fractionated Particulate Matter. Part. Fibre Toxicol. 2007, 4, 5. [CrossRef] 
118. Venkatachari, P.; Hopke, P.K. Development and Laboratory Testing of an Automated Monitor for the Measurement of Atmospheric Particle-Bound Reactive Oxygen Species (ROS). Aerosol Sci. Technol. 2008, 42, 629-635. [CrossRef]

119. Wragg, F.P.H.; Fuller, S.J.; Freshwater, R.; Green, D.C.; Kelly, F.J.; Kalberer, M. An Automated Online Instrument to Quantify Aerosol-Bound Reactive Oxygen Species (ROS) for Ambient Measurement and Health-Relevant Aerosol Studies. Atmos. Meas. Tech. 2016, 9, 4891-4900. [CrossRef]

120. Berg, K.E.; Clark, K.M.; Li, X.; Carter, E.M.; Volckens, J.; Henry, C.S. High-Throughput, Semi-Automated Dithiothreitol (DTT) Assays for Oxidative Potential of Fine Particulate Matter. Atmos. Environ. 2020, 222, 117132. [CrossRef]

121. Fang, T.; Verma, V.; Guo, H.; King, L.E.; Edgerton, E.S.; Weber, R.J. A Semi-Automated System for Quantifying the Oxidative Potential of Ambient Particles in Aqueous Extracts Using the Dithiothreitol (DTT) Assay: Results from the Southeastern Center for Air Pollution and Epidemiology (SCAPE). Atmos. Meas. Tech. 2015, 8, 471-482. [CrossRef]

122. Eiguren-Fernandez, A.; Kreisberg, N.; Hering, S. An Online Monitor of the Oxidative Capacity of Aerosols (o-MOCA). Atmos. Meas. Tech. 2017, 10, 633-644. [CrossRef] [PubMed]

123. Puthussery, J.V.; Zhang, C.; Verma, V. Development and Field Testing of an Online Instrument for Measuring the Real-Time Oxidative Potential of Ambient Particulate Matter Based on Dithiothreitol Assay. Atmos. Meas. Tech. 2018, 11, 5767-5780. [CrossRef]

124. Son, Y.; Mishin, V.; Welsh, W.; Lu, S.-E.; Laskin, J.D.; Kipen, H.; Meng, Q. A Novel High-Throughput Approach to Measure Hydroxyl Radicals Induced by Airborne Particulate Matter. Int. J. Environ. Res. Public Health 2015, 12, 13678-13695. [CrossRef]

125. Yu, H.; Puthussery, J.V.; Verma, V. A Semi-Automated Multi-Endpoint Reactive Oxygen Species Activity Analyzer (SAMERA) for Measuring the Oxidative Potential of Ambient PM2.5 Aqueous Extracts. Aerosol Sci. Technol. 2019, 54, 304-320. [CrossRef]

126. Quinn, C.; Miller-Lionberg, D.D.; Klunder, K.J.; Kwon, J.; Noth, E.M.; Mehaffy, J.; Leith, D.; Magzamen, S.; Hammond, S.K.; Henry, C.S.; et al. Personal Exposure to PM2.5 Black Carbon and Aerosol Oxidative Potential Using an Automated Microenvironmental Aerosol Sampler (AMAS). Environ. Sci. Technol. 2018, 52, 11267-11275. [CrossRef]

127. Brehmer, C.; Lai, A.; Clark, S.; Shan, M.; Ni, K.; Ezzati, M.; Yang, X.; Baumgartner, J.; Schauer, J.J.; Carter, E. The Oxidative Potential of Personal and Household PM2.5 in a Rural Setting in Southwestern China. Environ. Sci. Technol. 2019, 53, 2788-2798. [CrossRef]

128. Roper, C.; Perez, A.; Barrett, D.; Hystad, P.; Massey Simonich, S.L.; Tanguay, R.L. Workflow for Comparison of Chemical and Biological Metrics of Filter Collected PM2.5. Atmos. Environ. 2020, 226, 117379. [CrossRef]

129. Brehmer, C.; Norris, C.; Barkjohn, K.K.; Bergin, M.H.; Zhang, J.; Cui, X.; Teng, Y.; Zhang, Y.; Black, M.; Li, Z.; et al. The Impact of Household Air Cleaners on the Oxidative Potential of PM2.5 and the Role of Metals and Sources Associated with Indoor and Outdoor Exposure. Environ. Res. 2020, 181, 108919. [CrossRef]

130. Zhan, Y.; Johnson, K.; Norris, C.; Shafer, M.M.; Bergin, M.H.; Zhang, Y.; Zhang, J.; Schauer, J.J. The Influence of Air Cleaners on Indoor Particulate Matter Components and Oxidative Potential in Residential Households in Beijing. Sci. Total Environ. 2018, 626, 507-518. [CrossRef] [PubMed]

131. Charrier, J.G.; Richards-Henderson, N.K.; Bein, K.J.; McFall, A.S.; Wexler, A.S.; Anastasio, C. Oxidant Production from Source-Oriented Particulate Matter-Part 1: Oxidative Potential Using the Dithiothreitol (DTT) Assay. Atmos. Chem. Phys. 2015, 15, 2327-2340. [CrossRef]

132. Pirhadi, M.; Mousavi, A.; Taghvaee, S.; Shafer, M.M.; Sioutas, C. Semi-Volatile Components of PM2.5 in an Urban Environment: Volatility Profiles and Associated Oxidative Potential. Atmos. Environ. 2020, 223, 117197. [CrossRef] [PubMed]

133. Verma, V.; Rico-Martinez, R.; Kotra, N.; King, L.; Liu, J.; Snell, T.W.; Weber, R.J. Contribution of Water-Soluble and Insoluble Components and Their Hydrophobic/Hydrophilic Subfractions to the Reactive Oxygen Species-Generating Potential of Fine Ambient Aerosols. Environ. Sci. Technol. 2012, 46, 11384-11392. [CrossRef]

134. CARB. Determination of Reactive Oxygen Species Activity in PM and Enhanced Exposure Assessment for the NIH, NIEHS Study Entitled: Ultrafine Particulate Matter and Cardiorespiratory Health; California Air Resources Board and the California Environmental Protection Agency: Street Sacramento, CA, USA, 2009. Available online: http://www.arb.ca.gov/research/apr/past/03-329.pdf (accessed on 29 May 2020). 
135. Verma, V.; Fang, T.; Guo, H.; King, L.; Bates, J.T.; Peltier, R.E.; Edgerton, E.; Russell, A.G.; Weber, R.J. Reactive Oxygen Species Associated with Water-Soluble PM2.5 in the Southeastern United States: Spatiotemporal Trends and Source Apportionment. Atmos. Chem. Phys. 2014, 14, 12915-12930. [CrossRef]

136. Saffari, A.; Daher, N.; Shafer, M.M.; Schauer, J.J.; Sioutas, C. Global Perspective on the Oxidative Potential of Airborne Particulate Matter: A Synthesis of Research Findings. Environ. Sci. Technol. 2014, 48, 7576-7583. [CrossRef]

137. Mirowsky, J.E.; Jin, L.; Thurston, G.; Lighthall, D.; Tyner, T.; Horton, L.; Galdanes, K.; Chillrud, S.; Ross, J.; Pinkerton, K.E.; et al. In Vitro and in Vivo Toxicity of Urban and Rural Particulate Matter from California. Atmos. Environ. 2015, 103, 256-262. [CrossRef]

138. Jomova, K.; Valko, M. Advances in Metal-Induced Oxidative Stress and Human Disease. Toxicology 2011, 283, 65-87. [CrossRef]

139. Verma, V.; Ning, Z.; Cho, A.K.; Schauer, J.J.; Shafer, M.M.; Sioutas, C. Redox Activity of Urban Quasi-Ultrafine Particles from Primary and Secondary Sources. Atmos. Environ. 2009, 43, 6360-6368. [CrossRef]

140. Frank, L.D.; Iroz-Elardo, N.; MacLeod, K.E.; Hong, A. Pathways from Built Environment to Health: A Conceptual Framework Linking Behavior and Exposure-Based Impacts. J. Transp. Health 2019, 12, 319-335. [CrossRef]

141. Künzli, N.; Mudway, I.S.; Götschi, T.; Shi, T.; Kelly, F.J.; Cook, S.; Burney, P.; Forsberg, B.; Gauderman, J.W.; Hazenkamp, M.E.; et al. Comparison of Oxidative Properties, Light Absorbance, and Total and Elemental Mass Concentration of Ambient PM2.5 Collected at 20 European Sites. Environ. Health Perspect. 2006, 114, 684-690. [CrossRef] [PubMed]

142. Risom, L.; Dybdahl, M.; Bornholdt, J.; Vogel, U.; Wallin, H.; Møller, P.; Loft, S. Oxidative DNA Damage and Defense Gene Expression in the Mouse Lung after Short-Term Exposure to Diesel Exhaust Particles by Inhalation. Carcinogenesis 2003, 24, 1847-1852. [CrossRef] [PubMed]

143. Sørensen, M.; Autrup, H.; Møller, P.; Hertel, O.; Jensen, S.S.; Vinzents, P.; Knudsen, L.E.; Loft, S. Linking Exposure to Environmental Pollutants with Biological Effects. Mutat. Res. Rev. Mutat. 2003, 544, 255-271. [CrossRef] [PubMed]

144. Squadrito, G.L.; Cueto, R.; Dellinger, B.; Pryor, W.A. Quinoid Redox Cycling as a Mechanism for Sustained Free Radical Generation by Inhaled Airborne Particulate Matter. Free Radic. Biol. Med. 2001, 31, 1132-1138. [CrossRef]

145. Penning, T.M.; Burczynski, M.E.; Hung, C.F.; McCoull, K.D.; Palackal, N.T.; Tsuruda, L.S. Dihydrodiol Dehydrogenases and Polycyclic Aromatic Hydrocarbon Activation: Generation of Reactive and Redox Active o-Quinones. Chem. Res. Toxicol. 1999, 12, 1-18. [CrossRef]

146. McWhinney, R.D.; Badali, K.; Liggio, J.; Li, S.M.; Abbatt, J.P.D. Filterable Redox Cycling Activity: A Comparison between Diesel Exhaust Particles and Secondary Organic Aerosol Constituents. Environ. Sci. Technol. 2013, 47, 3362-3369. [CrossRef]

147. Cheng, W.Y.; Currier, J.; Bromberg, P.A.; Silbajoris, R.; Simmons, S.O.; Samet, J.M. Linking Oxidative Events to Inflammatory and Adaptive Gene Expression Induced by Exposure to an Organic Particulate Matter Component. Environ. Health Perspect. 2012, 120, 267-274. [CrossRef]

148. Taguchi, K.; Fujii, S.; Yamano, S.; Cho, A.K.; Kamisuki, S.; Nakai, Y.; Sugawara, F.; Froines, J.R.; Kumagai, Y. An Approach to Evaluate Two-Electron Reduction of 9,10-Phenanthraquinone and Redox Activity of the Hydroquinone Associated with Oxidative Stress. Free Radic. Biol. Med. 2007, 43, 789-799. [CrossRef]

149. Saffari, A.; Daher, N.; Shafer, M.M.; Schauer, J.J.; Sioutas, C. Seasonal and Spatial Variation in Dithiothreitol (DTT) Activity of Quasi-Ultrafine Particles in the Los Angeles Basin and Its Association with Chemical Species. J. Environ. Sci. Health Part A Toxic Hazard. Substain. Environ. Eng. 2014, 49, 441-451. [CrossRef]

150. Happo, M.S.; Hirvonen, M.R.; Halinen, A.I.; Jalava, P.I.; Pennanen, A.S.; Sillanpaa, M.; Hillamo, R.; Salonen, R.O. Chemical Compositions Responsible for Inflammation and Tissue Damage in the Mouse Lung by Coarse and Fine Particulate Samples from Contrasting Air Pollution in Europe. Inhal. Toxicol. 2008, 20, 1215-1231. [CrossRef]

151. Kramer, A.J.; Rattanavaraha, W.; Zhang, Z.; Gold, A.; Surratt, J.D.; Lin, Y.-H. Assessing the Oxidative Potential of Isoprene-Derived Epoxides and Secondary Organic Aerosol. Atmos. Environ. 2016, 130, $211-218$. [CrossRef] 
152. Arashiro, M.; Lin, Y.-H.; Zhang, Z.; Sexton, K.G.; Gold, A.; Jaspers, I.; Fry, R.C.; Surratt, J.D. Effect of Secondary Organic Aerosol from Isoprene-Derived Hydroxyhydroperoxides on the Expression of Oxidative Stress Response Genes in Human Bronchial Epithelial Cells. Environ. Sci. Process. Impacts 2018, 20, 332-339. [CrossRef] [PubMed]

153. McWhinney, R.D.; Zhou, S.; Abbatt, J.P.D. Naphthalene SOA: Redox Activity and Naphthoquinone Gas-Particle Partitioning. Atmos. Chem. Phys. 2013, 13, 9731-9744. [CrossRef]

154. Tuet, W.Y.; Chen, Y.; Xu, L.; Fok, S.; Gao, D.; Weber, R.J.; Ng, N.L. Chemical Oxidative Potential of Secondary Organic Aerosol (SOA) Generated from the Photooxidation of Biogenic and Anthropogenic Volatile Organic Compounds. Atmos. Chem. Phys. 2017, 17, 839-853. [CrossRef]

155. Tong, H.; Lakey, P.S.J.; Arangio, A.M.; Socorro, J.; Shen, F.; Lucas, K.; Brune, W.H.; Pöschl, U.; Shiraiwa, M. Reactive Oxygen Species Formed by Secondary Organic Aerosols in Water and Surrogate Lung Fluid. Environ. Sci. Technol. 2018, 52, 11642-11651. [CrossRef]

156. Fang, T.; Guo, H.; Zeng, L.; Verma, V.; Nenes, A.; Weber, R.J. Highly Acidic Ambient Particles, Soluble Metals, and Oxidative Potential: A Link between Sulfate and Aerosol Toxicity. Environ. Sci. Technol. 2017, 51, 2611-2620. [CrossRef]

157. Gao, D.; Ripley, S.; Weichenthal, S.; Godri Pollitt, K.J. Ambient Particulate Matter Oxidative Potential: Chemical Determinants, Associated Health Effects, and Strategies for Risk Management. Free Radic. Biol. Med. 2020, 151, 7-25. [CrossRef]

158. Samake, A.; Uzu, G.; Martins, J.M.F.; Calas, A.; Vince, E.; Parat, S.; Jaffrezo, J.L. The Unexpected Role of Bioaerosols in the Oxidative Potential of PM. Sci. Rep. 2017, 7, 10978. [CrossRef]

159. Yu, H.; Wei, J.; Cheng, Y.; Subedi, K.; Verma, V. Synergistic and Antagonistic Interactions among the Particulate Matter Components in Generating Reactive Oxygen Species Based on the Dithiothreitol Assay. Environ. Sci. Technol. 2018, 52, 2261-2270. [CrossRef]

160. Lin, M.; Yu, J.Z. Effect of Metal-Organic Interactions on the Oxidative Potential of Mixtures of Atmospheric Humic-like Substances and Copper/Manganese as Investigated by the Dithiothreitol Assay. Sci. Total Environ. 2019, 697, 134012. [CrossRef]

161. Guo, H.; Fu, H.; Jin, L.; Huang, S.; Li, X. Quantification of Synergistic, Additive and Antagonistic Effects of Aerosol Components on Total Oxidative Potential. Chemosphere 2020, 252, 126573. [CrossRef] [PubMed]

162. Li, N.; Sioutas, C.; Cho, A.; Schmitz, D.; Misra, C.; Sempf, J.; Wang, M.; Oberley, T.; Froines, J.; Nel, A. Ultrafine Particulate Pollutants Induce Oxidative Stress and Mitochondrial Damage. Environ. Health Perspect. 2003, 111, 455-460. [CrossRef] [PubMed]

163. Ohlwein, S.; Kappeler, R.; Kutlar Joss, M.; Künzli, N.; Hoffmann, B. Health Effects of Ultrafine Particles: A Systematic Literature Review Update of Epidemiological Evidence. Int. J. Public Health 2019, 64, 547-559. [CrossRef] [PubMed]

164. Lyu, Y.; Guo, H.; Cheng, T.; Li, X. Particle Size Distributions of Oxidative Potential of Lung-Deposited Particles: Assessing Contributions from Quinones and Water-Soluble Metals. Environ. Sci. Technol. 2018, 52, 6592-6600. [CrossRef] [PubMed]

165. Saffari, A.; Daher, N.; Shafer, M.; Schauer, J.; Sioutas, C. Toxic Potential of Ambient Particulate Matter in Various Urban Areas of the World and Its Relation to Chemical Composition and Emission Sources. Eur. Respir. J. 2014, 44, 4132.

166. Cheung, K.L.; Polidori, A.; Ntziachristos, L.; Tzamkiozis, T.; Samaras, Z.; Cassee, F.R.; Gerlofs, M.; Sioutas, C. Chemical Characteristics and Oxidative Potential of Particulate Matter Emissions from Gasoline, Diesel, and Biodiesel Cars. Environ. Sci. Technol. 2009, 43, 6334-6340. [CrossRef]

167. Sauvain, J.-J.; Deslarzes, S.; Riediker, M. Nanoparticle Reactivity toward Dithiothreitol. Nanotoxicology 2008, 2, 121-129. [CrossRef]

168. Breznan, D.; Nazemof, N.; Kunc, F.; Hill, M.; Vladisavljevic, D.; Gomes, J.; Johnston, L.J.; Vincent, R.; Kumarathasan, P. Acellular Oxidative Potential Assay for Screening of Amorphous Silica Nanoparticles. Analyst 2020, 145, 4867-4879. [CrossRef]

169. Liu, Q.; Shahpoury, P.; Liggio, J.; Harner, T.; Li, K.; Lee, P.; Li, S.-M. Understanding the Key Role of Atmospheric Processing in Determining the Oxidative Potential of Airborne Engineered Nanoparticles. Environ. Sci. Technol. Lett. 2020, 7, 7-13. [CrossRef] 
170. Cesari, D.; Merico, E.; Grasso, F.M.; Decesari, S.; Belosi, F.; Manarini, F.; de Nuntiis, P.; Rinaldi, M.; Volpi, F.; Gambaro, A.; et al. Source Apportionment of PM2.5 and of Its Oxidative Potential in an Industrial Suburban Site in South Italy. Atmosphere 2019, 10, 758. [CrossRef]

171. Yang, A.; Wang, M.; Eeftens, M.; Beelen, R.; Dons, E.; Leseman, D.L.A.C.; Brunekreef, B.; Cassee, F.R.; Janssen, N.A.H.; Hoek, G. Spatial Variation and Land Use Regression Modeling of the Oxidative Potential of Fine Particles. Environ. Health Perspect. 2015, 123, 1187-1192. [CrossRef] [PubMed]

172. Jedynska, A.; Hoek, G.; Wang, M.; Yang, A.; Eeftens, M.; Cyrys, J.; Keuken, M.; Ampe, C.; Beelen, R.; Cesaroni, G.; et al. Spatial Variations and Development of Land Use Regression Models of Oxidative Potential in Ten European Study Areas. Atmos. Environ. 2017, 150, 24-32. [CrossRef]

173. Gulliver, J.; Morley, D.; Dunster, C.; McCrea, A.; van Nunen, E.; Tsai, M.-Y.; Probst-Hensch, N.; Eeftens, M.; Imboden, M.; Ducret-Stich, R.; et al. Land Use Regression Models for the Oxidative Potential of Fine Particles (PM 2.5 ) in Five European Areas. Environ. Res. 2018, 160, 247-255. [CrossRef] [PubMed]

174. Weichenthal, S.; Shekarrizfard, M.; Traub, A.; Kulka, R.; Al-Rijleh, K.; Anowar, S.; Evans, G.; Hatzopoulou, M. Within-City Spatial Variations in Multiple Measures of PM2.5 Oxidative Potential in Toronto, Canada. Environ. Sci. Technol. 2019, 53, 2799-2810. [CrossRef] [PubMed]

175. Yang, A.; Hoek, G.; Montagne, D.; Leseman, D.L.A.C.; Hellack, B.; Kuhlbusch, T.A.J.; Cassee, F.R.; Brunekreef, B.; Janssen, N.A.H. Agreement of Central Site Measurements and Land Use Regression Modeled Oxidative Potential of PM2.5 with Personal Exposure. Environ. Res. 2015, 140, 397-404. [CrossRef]

176. Hellack, B.; Sugiri, D.; Schins, R.P.F.; Schikowski, T.; Krämer, U.; Kuhlbusch, T.A.J.; Hoffmann, B. Land Use Regression Modeling of Oxidative Potential of Fine Particles, $\mathrm{NO}_{2}$, PM2.5 Mass and Association to Type Two Diabetes Mellitus. Atmos. Environ. 2017, 171, 181-190. [CrossRef]

(C) 2020 by the authors. Licensee MDPI, Basel, Switzerland. This article is an open access article distributed under the terms and conditions of the Creative Commons Attribution (CC BY) license (http://creativecommons.org/licenses/by/4.0/). 